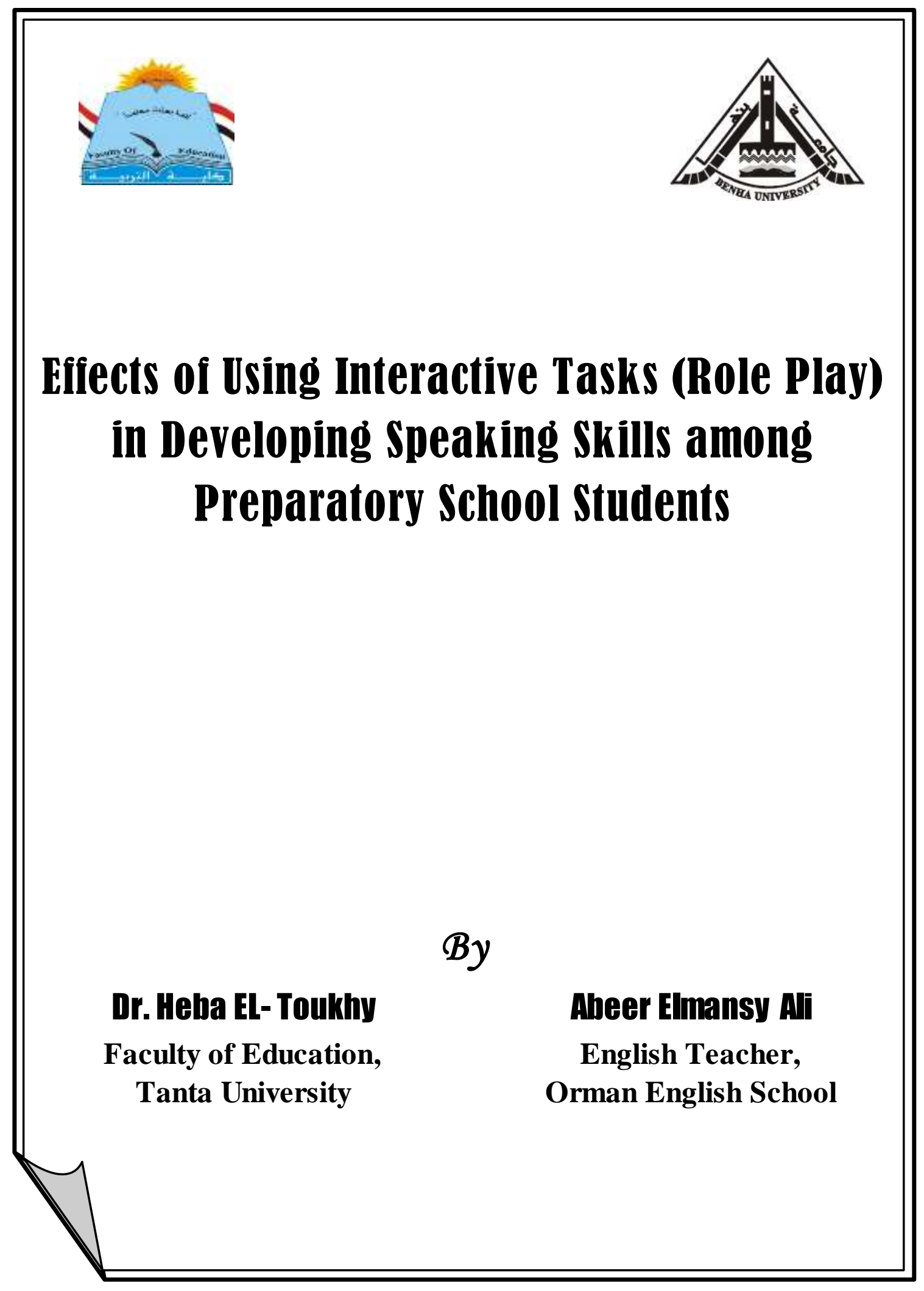




\section{Effects of Using Interactive Tasks (Role Play) in Developing Speaking Skills among Preparatory School Students}

By

Dr. Heba EL-Toukhy

Faculty of Education, Tanta University

\section{Aheer Elmansy Ali}

English Teacher, Orman English School

\section{Alustract}

The study aimed at investigating the Effects of Interactive Tasks namely role-play in Developing English Speaking Skills among Preparatory School Students. This study was conducted on 60 students of first prep school students. These participants were selected randomly from Orman English School in El-Gharbia Governorate, in the school year 2018/2019. The participants were assigned to experimental and control groups; 30 students per each. Students of the experimental group were taught using interactive tasks (role play). On the other hand the students of the control group were taught in the traditional way. Results of the study indicated that there was significant developing in favor of the experimental group concerning speaking skills (fluency) among first preparatory school students. A group of recommendation was accordingly provided to EFL teachers, course designers, and future TEFL researcher.

Keywords: interactive tasks -role play-fluency. 


\section{Introduction}

Speaking is considered the most important skills in English as a foreign language because it helps others to communicate in real life situation. Speaking requires making the right sounds, choosing the appropriate words and getting the right tense. Speaking is an essential language skill for foreign language learners to express themselves well in communicative situations (Ammar, 2017).

During speaking the speaker should think of the idea s/he wants to express, choosing the vocabulary, knowing the structure, sounds, and the cultural of the language .The main goal of speaking is to develop learner's oral fluency, so the students who have a strong oral language have a unique characteristic during speaking. Students give a high priority to speaking because it is the most important aspect of language teaching. That is the main goal why the development of speaking skill as a foreign language course (El Feky ,2016).

Foreign language learners enhance their speaking during interaction. So that communication serves this goal as it is based on real life. It plays an important part for EFL learners to communicate with their teachers and peers inside the classroom and therefore, EFL teachers should create a school environment where learners have real life situations and conversations that promote their language (kayi,2006).

In spite of the importance of the speaking skill, it is usually neglected in EFL classroom. There is no interest in teaching speaking English in the classroom because learners have written tests not speaking. so, students aren't able to speak English well(Ahmed, 2000).In addition to, there are no mid-or final-term speaking tests that can encourage students to improve their speaking proficiency (Shehata,2008).

A suggested way to encourage learners to speak and share in oral classroom activities is using interactive tasks which proved in previous studies such as (Khadija, 2010) to be very effective. Examples of effective interactive tasks activities are: storytelling, debate, role -play, 
interview, peer feedback, oral games and discussion. This study focuses on role-paly which proved in previous studies in enhancing speaking skills which proved in previous studies like that of (Meilyaningsih,2014 and Ismail, 2017) to be effective in enhancing speaking skills.

Role-play: is a method of instruction in which participants act out designated role which is relevant to real-life situation. It is a technique which encourages the students and builds their self confidence through speaking. It also promotes the effective interpersonal and social relationships among participants (Teed,2009).

According to Teed (2009) the advantages of role-play are the following:

1- Using role-playing activities increases students' self-esteem and shows them that they can be successful in communication process and situations.

2- Practicing role play creates low-anxiety learning environment and increases sympathy among the students.

3- Improving students' languages skill and shows their variety of experience.

\section{Types of Interaction}

Two types of interaction have been cited frequently in the literature: Learner-learner interaction and learner-teacher interaction (Thurmond, 2003).

\section{1- Learner-Learner Interaction}

It encourages the learners to enhance their speaking because it makes learners active rather than passive participants. Students work together in partners or groups to learn content and discuss their learning. Student interaction is important because it provides opportunities for extended language output (Look,2010). 


\section{2- Teacher-Learner Interaction}

It means that the teacher participates in interaction. He starts to discuss with his students the content during asking questions, listening to students ${ }^{\text {ee }}$ ideas, lectures, giving directions, or justifying learner speak responses. Teacher-talk serves as a language model for students, offers opportunities to expand language skills and reinforces students (Look,2010).

\section{Statement of the Problem}

In response to some speaking problems among prep school students this research is an attempt to investigate the effect of using interactive tasks namely (role-play) in developing speaking skill (fluency) of first year prep school students.

\section{Aim of the study}

The ultimate goal of this study is to develop students who have major problems in speaking fluency. So using role play will give the students opportunities to speak.

\section{Significance of the study}

This study addresses the development of speaking skill of first year prep school students. The current literature confirms the importance of shedding more light on interactive tasks strategies. The study attempts to develop students' speaking skill through concentrating on fluency. This study has a great importance to the curriculum designer, as it helps him when designing the curriculum to take into consideration how students improve their speaking best, so he will design and insert In the curriculum he appreciate exercise that will help students more and more to master that skill.

\section{Question of the study}

What is the effect of using interactive tasks (role-play) on first year Preparatory school students' speaking fluency? 


\section{Hypotheses of the study}

1- There are a statistically significant differences in the mean score relative to fluency on the speaking test between the pretest and the post test for experimental group in favor of the post test.

2- There are significant differences in the mean score relative to fluency on the post test between the experimental and control group in favor of the experimental group.

\section{Delimitation of the study} The present study is delimited to:

1- Only a selected sample of language school, first preparatory school students.

2- This study only examines certain aspect of speaking skills which is:

a) Speaking fluency.

3- Using only one strategy of interactive tasks; namely role play.

4- Concentration on two types of interaction:

a) Teacher - learner interaction.

b) Learner- learner interaction.

\section{Sample of the study:}

Two intact classes selected from Orman English School of first year prep school students. The two classes are assigned to an experimental group and a control group.

\section{Instruments of the study}

- Pre post speaking tests (tape recorded interviews).

- A scoring rubric.

\section{Design of the study}

This study was conducted on first year preparatory school students. Two intact classes were chosen from Orman English School in El-Gharbia Governorate in the second term of the year2018/2019. Participants were assigned to experimental and control groups 30 students for each. 


\section{Related studies}

Abdullah(2015) investigated the impact of using some interactive teaching strategies on improving the EFL speaking skills for preparatory stage pupils namely, brainstorming, role playing and classroom discussion. The sample of this quasi experimental study consisted of 70 pupils in the second year preparatory stage at Koum Bani Meras preparatory school. They were selected randomly and were assigned to a control group and an experimental one. Two instruments were used in this study, namely a questionnaire to determine the speaking skills appropriate for the sample and a pre- post speaking test. $\mathrm{T}$ test was used to compare the mean score of the control and experimental group (using some interactive teaching strategies) outperformed the control group on the post administration of the speaking test. The results of using interactive teaching strategies had positive effects on improving speaking skills of the target sample.

Saaied (2015) investigates the positive influence of classroom interaction on students speaking proficiency. This study aims to improve students' oral proficiency, to create several strategies that fit the learners speaking abilities according to their level of achievement, and it also aims to guide the learners to interact more with the teacher, content and with each other. The tools are two questionnaires were designed for both students and teachers were chosen randomly. As a result, integrating different types of classroom activities which are related to students' interaction can both enhance their speaking proficiency and help EFL teachers to control their classes. This study attempted to offer a brief overview of classroom interaction, the study also suggested specific teaching speaking strategies and various classroom activities; this in turn, allows students to interact, speak and participate in a way that is associated to their speaking styles.

Ismail(2017) investigated the effectiveness of using simulation and role-play in improving speaking skill. The sample of this study was 
40 students of Form Sekolah Agama Menengah (SAM) Muhammadiah, Sabak Bernam were involved in completing the performance test and questionnaires. The result of this study showed many positive signs in the students because they enjoyed the simulation and role-play activities. This study showed that through simulation and role-play, teachers can help their students improve their speaking skills and bring positive changes in the class as well.

Meilyaningsih (2014) investigated the effectiveness of using roleplay in improving Grade VIII students' speaking ability in SMPN 1 Banguntapan. The sample of this study consisted of two cycles. The researcher worked collaboratively with the English teacher, the students, and the collaborators. The tools of this study were observing the teaching and learning process, and interviewing the students. The results of this research showed that the use of Role Playing technique was successful to improve the students' speaking ability. Role Play technique was successful to encourage them to practice speaking.

\section{Definition of terms:}

\section{The following terms were used in the study:}

Interactive tasks are an effective format of instruction that makes learning a shared social experience. Students and teachers learn from one another because they work together, observing, discussing, questioning, sharing, and transferring knowledge. Through these interactions, students learn content knowledge and how to work in groups, an important social skill for life (Look, 2011).

Fluency: "The ability to express oneself in an intelligible, reasonable and accurate way without too much hesitation" (Hughes, 2002, cited in Khadidja, 2009).

\section{Procedures:}

In this step all materials are prepared and the researcher explained to students how to use the two types of interaction (Teacher - learner interaction and learner- learner interaction) and how to apply this activity (role play) of interactive tasks, as the following: 
Teacher - learner interaction occurs between the teacher and many other learners; it means that the teacher takes a part in interaction. The teacher starts to negotiate with her students the content of the course by asking questions, listening to students' ideas, giving directions, criticizing or justifying student talk responses. Moreover, the students will benefit from the experience of their teachers and how to deal well with interact in the manner that is most effective. And the teacher should focus on three things when they talk with their students. 1- The teacher must pay attention to the kind of the language the students are able to understand. 2- The teachers must think about what they will say to their students, hence the teacher speech is as a resource for learners. 3-the teachers also have to identify the ways in which they will speak such as the voice, tone and intonation).

Learner- learner interaction the teachers must encourage this type of interaction between learners because it is the fastest and the best way to help them to improve their speaking because it makes learners active rather than passive participants and talking students with their peers about the content of the course is a powerful way for them to reinforce what they have learned.

During role paly the researcher decided which material were used for role play activities; theses material should suit to students' level, teaching objectives and interests. The researcher explained the topic for the students according to (Teacher- learner interaction) to be aware of the content of the role play. Students worked in pairs according to (learner- learner interaction) to role play and act it during (speaker A and speaker B) and when they played their roles they could exchange the roles. The increase of the students' speaking time during interactive tasks activity might have given students a good opportunity to practice speaking and express themselves freely. 


\section{Results and Discussion}

Analysis and presentation of the results related to the question of the study:

What is the effect of using interactive tasks (role-play) on first year Preparatory school students' speaking fluency?

\section{Hypothesis one}

The hypothesis one was: there are a statistically significant differences in the mean score relative to fluency on the speaking test between the pretest and the post test for experimental group in favor of the post test.

Table (1): T-test analysis results for pre and post-test scores of the students' Speaking skills of the experimental groups on fluency

\begin{tabular}{|c|c|c|c|c|c|c|c|}
\hline Speaking Skills & $\begin{array}{c}\text { Pre-post } \\
\text { Exp }\end{array}$ & $\mathbf{N}$ & $\mathbf{x}^{-}$ & SD & Df & T & $\begin{array}{c}\text { Sig } \\
\text { (2- tailed) }\end{array}$ \\
\hline \hline \multirow{2}{*}{ Fluency } & Pre-test & 30 & 1.37 & .49 & \multirow{2}{*}{29} & 22.66 & \multirow{2}{*}{$.000^{*}$} \\
\cline { 2 - 6 } & Post-test & 30 & 2.53 & .57 & & & \\
\hline
\end{tabular}

Table (1) showed that the mean scores were 1,37 and2.53, the SD were .49 and .57 between the pretest and the post test for the experimental group in favor of the post test respectively; ( $\mathrm{df}=29$ $, \mathrm{t}=22,66 \mathrm{p}=.000<0.05)$. In other words, the table indicates a statistically significant difference in favor of the post for the experimental group concerning the fluency. The fourth hypothesis was supported.

\section{Hypothesis two}

The hypothesis two was: there are significant differences in the mean score relative to fluency on the post -test between the experimental and control group in favor of the experimental group. To validate this hypothesis, the t-test was applied on fluency and the results were as shown in the following tables:

\begin{tabular}{|c|c|c|c|c|c|c|c||}
\hline \hline Speaking Skills & Group & $\mathrm{N}$ & $\mathrm{x}^{-}$ & $\mathrm{SD}$ & $\mathrm{df}$ & $\mathrm{T}$ & $\begin{array}{c}\text { Sig } \\
(2-\text { tailed })\end{array}$ \\
\hline \hline \multirow{2}{*}{ Fluency } & Control & 30 & 1.50 & .51 & \multirow{2}{*}{57} & \multirow{2}{*}{7.39} \\
\cline { 2 - 6 } & Experimental & 30 & 2.53 & .57 & & \\
\hline
\end{tabular}


Table (2): T-test analysis results for post-test scores of the control and experimental groups on fluency

Table (2) showed that the mean scores were 1,50 and 2,53,the SD were .51 and .57 for the control and experimental groups respectively; ( $\mathrm{df}=57, \mathrm{t}=7,39 \mathrm{p}=.000<0.05)$. In other words, the table indicates a statistically significant difference in favor of the experimental group concerning the fluency .The hypothesis was supported.

\section{Discussion}

The results of the t-test showed using interactive tasks namely role-paly on developing students' fluency. The Fluency means scores of the students at the end of experiment, were found higher significantly than means scores at the beginning of the experiment. This confirms previous findings the using interactive tasks(role-play) had a significant effect on the fluency skill of students.

This means that the interactive tasks activities had been effective in enhancing the experimental group students' fluency. The experimental group achieved progress in fluency for some reasons: the interactive tasks activity was influential and motivating. The increase of the students' speaking time during interactive tasks activity might have given students a good opportunity to practice speaking and express themselves freely.

Moreover, students participated in communicative activity to practice interactive tasks activities efficiently. Some of these activities included (role play) which enabled the students to read the full sentences and after practicing this activity they were able to say the full sentence as a real life situation.

This activity might have improved fluency by encouraging the students to better express themselves. Also, errors were not corrected directly, but were delayed to the end of each session. This might have had a positive effect on fluency as students were not afraid of being embarrassed. Furthermore, the increasing of speaking time may have had a positive reflection on fluency. A relaxed person is expected to be more fluent than an anxious person whose unpleasant feelings might interfere with his ability to speak fluently. Thus, students could practice speaking smoothly with some pauses and hesitations. 


\section{Conclusion}

The present study provided evidence for the effects of Interactive Tasks namely role-play in developing first year preparatory students' speaking skills. This activity increased students' confidence and ability to speak. Students achieved improvements in their speaking fluency. Thus, using interactive tasks helped students promote their speaking performance.

In addition, the change in the teacher's role from an authoritarian to an organizer, a facilitator and a language adviser allowed students to share more responsibilities for their learning, express themselves freely and become the center of the learning process.

Thus, the adoption of interactive tasks is beneficial for students in improving their speaking performance .This has been supported by the results of the present study as achieved by the participants of the experimental group.

\section{Recommendations}

On the basis of the results of this study, the following recommendations are offered:

1- Students should be provided with real learning situations that might enhance in developing their speaking performance.

2- Students should know how to plan for their spoken performance in advance to lower the burden on their cognitive ability during speaking.

3- The teacher should become a motivator, a guide and participant in learning process to create more opportunities for students to speak.

4- Preparatory school exams should include the speaking skill. This helps students and teachers to give more focus on speaking. 


\section{References}

Abdullah, H. (2015). The Effect of Interactive Teaching Strategies Enhancing EFL Speaking Skills. Faculty of Education, Mansoura University.

Ahmed, A. M. (2000).Evaluation of the speaking skills in the English language course for students of the first grade of the secondary stage. Unpublished master's thesis. Institute of Educational studies, Cairo University.

Ammar, M. (2017). The Effectiveness of Using Meaning Negotiation Strategies in Developing First Year Secondary Students' Speaking Skills. Faculty of Education, Tanta University.

Al-Sabagh, A. (2009).The Effectiveness of Multi-Media Short Stories in Developing the Speaking Skill of First Year Secondary School Students. Faculty of Education, Tanta University.

Chaney, A., and T. L. Burk. 1998. Teaching Oral Communication in Grades K-8. Boston: Allyn \& Bacon.

El-Feky, D (2016). The Effectiveness of Dialogic Reading in Enhance Speaking Performance Among Third Grade Experimental Language Schools Students, Ph. D. dissertation, faculty of education, Tanta University.

Graves, K. (2008) .The language curriculum: A social contextual perspective.' Language Teaching 41(2), 147-181.

Hassan, E. (2009). The effectiveness of two metacognitive strategies in developing EFL prospective teachers' speaking skill.

Ismail, R. (2017). The Use of Simulation and Role-Play in Enhancing Speaking Skills in Learning English Language. University Malaysia Pahang. 
Kayi, H. (2006). Teaching Speaking: Activities to Promote Speaking in a Second Language, The Internet TESL Journal, Vol. XII, No. 11.

Khadidja, K. (2010). The Effect of Classroom Interaction on Developing The Learner's Speaking Skill. Mentouri University.

Look, sh. Effective Instruction Strategies Serial, Pactific Resources For Education and Learning, (2011).

Meilyaningsih, A. (2014). Improving the students' Speaking Ability through the Use of Role Playing Technique for Grade VIII Students of SMPN 1 Banguntapan.

Saaied, S. (2015). Enhancing EFL Learners' Speaking Skill through Classroom Interaction. Faculty of Letters' and Foreign University of Muhammad khieder Biskra.

Scrivener, J. (2005). Learning Teaching. Oxford, England: Macmilla Education.

Shehata, D. (2008).The Effectiveness of using Structured DiscussionDebate Technique in Developing First Year Secondary School Graders' Speaking Skill in English. Tanta University.

Thurmond, V. A. (2003). Examination of interaction variables as predictors of students' satisfaction and willingness to enroll in future Webbased courses while controlling for student characteristics. Published Dissertation. University of Kansas. Parkland, FL: Dissertation.com. Available online http://www.dissertation.com/library/1121814a.htm

Teed, R. (2009). Role playing exercises. Retrieved June 05, 2009 from $\begin{array}{llll}\text { Starting } & \text { Point } & \text { Web }\end{array}$ http://serc.carleton.edu/introgeo/roleplaying/ 


\section{Appendix [1]}

\section{The speaking test}

\section{The Speaking Rubrics}

\section{Speaking pre-test}

\section{A: Interview questions.}

1- What is your father's job?

2- What did you do last summer?

3- Which seasons do you prefer? Why?

4- Who is your best friend and Why?

5- Describe your house?

6- What is your favorite sport? Why?

7- Tell me about your family? (Mother, brother, sister, cous in,..)

8- What are you going to do next weekend?

9- What are the advantages and disadvantages of using the internet?

10- If you will be a teacher, which subject will you teach and why?

\section{Speaking post-test}

\section{A: Interview questions.}

1 - What is your mother's job?

2- What did you do last weekend?

3- Which subject do you prefer and why?

4- Who is your best teacher and Why?

5- Describe your school, what do you like most?

6- What do you prefer to do in your free time? (hobbies).

7- Can you tell me about the last movie you watched?

8- What are you going to do tomorrow?

9- What are the advantages and disadvantages of using the computer?

10- What do you want to be in the future and why?

The Speaking Rubrics

\begin{tabular}{|c|c|c|c|c|c||}
\hline Skill & $\begin{array}{c}\mathbf{5} \\
\text { Excellent }\end{array}$ & $\begin{array}{c}\mathbf{4} \\
\text { Good }\end{array}$ & $\begin{array}{c}\mathbf{3} \\
\text { Fair }\end{array}$ & $\begin{array}{c}\mathbf{2} \\
\text { Poor }\end{array}$ & $\begin{array}{c}\mathbf{1} \\
\text { Very poor }\end{array}$ \\
\hline \hline Fluency & $\begin{array}{c}\text { The student } \\
\text { can express } \\
\text { her/ himself } \\
\text { fluently } \\
\text { with no } \\
\text { pauses or } \\
\text { hesitation. }\end{array}$ & $\begin{array}{c}\text { The student can } \\
\text { expresser/ } \\
\text { himself fluently } \\
\text { with few pauses } \\
\text { or hesitation. }\end{array}$ & $\begin{array}{c}\text { Speech is } \\
\text { fairly slow } \\
\text { due to } \\
\text { noticeable } \\
\text { hesitation. }\end{array}$ & $\begin{array}{c}\text { Frequent pauses } \\
\text { and hesitation } \\
\text { that impede } \\
\text { communication } \\
\text { The student is } \\
\text { usually hesitant. }\end{array}$ & $\begin{array}{c}\text { Speech is } \\
\text { halting and } \\
\text { fragmentary. } \\
\text { Communication } \\
\text { is imped. }\end{array}$ \\
\hline
\end{tabular}




\section{Appendix[3]}

\section{Description of The Program}

\section{Lesson 1}

\section{Learning objectives:}

By the end of this lesson, students should be able to:

- Take apart in the role play in pairs.

- Relate the situation to previous experience they had.

- Use learner -learner interaction.

- Learn new structure.

\section{Activity: role play}

Topic: Tarek is asking Adel where he was on Saturday.

\section{The steps:}

1- The teacher presented some new words and structure(s) that can help the pupils perform the role play and then asked them to perform certain tasks to practice them before they start the role play, e.g. choose the right word, match, fill in spaces, pronounce words, etc.

2- Prepared the role-play cards.

3- Put students in pairs. Asked each student read one side of one role-play card, silently, to him/herself. When ready, have them begin the role-play.

4- The researcher should be sure that the students know how to use the sentences, vocabulary and dialogue to practice role play activities.

5- The students were able to practice the role play in pairs and when they played their roles they could exchange the roles. 
6- The researcher observed the students during practicing the activity and wrote all the comments.Then told the students about their mistakes.

7- The researcher could evaluate the effect of the role play activities by asking students some questions related to the role play activities and asked students to perform the role play.

8- At the end of this lesson the teacher gave the students some feedback about their performance during the role play with regard to use of vocab, grammar, pronunciation, and fluency and assigned them homework related to accuracy to be checked at the beginning of the following lesson. 